\title{
An Experimental Investigation Of Heat Transfer Characteristics In Plain And Tapered Spines
}

\author{
M. Krishna Prasanna ${ }^{1}$, P. Murari ${ }^{2}$, T. Siva Krishna ${ }^{3}$, M.R.Ch.Sastry ${ }^{4}$, Vamsi Krishna Salapati ${ }^{5}$ \\ ${ }^{1,2,3}$ Assistant Professor, ${ }^{4}$ Professor \& HoD, ${ }^{5}$ Graduate Student \\ ${ }^{1,2,3,4,5}$ Department of Mechanical Engineering, Gudlavalleru Engineering College \\ Email: prasannakrishna.268@gmail.com ${ }^{1}$
}

\begin{abstract}
In this work, experimental and numerical results of the heat transfer characteristics of the tapered spines under constant heat flux conditions are presented. An experimental set up has been used to analyze the heat transfer characteristics. The tapered spines are fabricated from cylindrical Aluminum 6061 alloy with length, base and tip diameters of 102, 12 and $(4,6,8) \mathrm{mm}$, respectively. Experiments are performed at various Reynolds numbers in the range of 1000-5000 and various heat inputs under forced convection. An observation has been noticed that the variable heat transfer coefficient has a strong influence over the spine effectiveness.
\end{abstract}

Key words: Tapered spine, heat flux, Reynolds number, forced convection

\section{INTRODUCTION}

The term extended surface is employed to depict a very important special case involving heat transfer by conduction within a solid and heat transfer by convection from the boundaries of the solid. There are many situations that involve combined conduction convection effects, the most frequent application is one in which an extended surface is used specifically to enhance heat transfer between a solid and an adjoining fluid. Such an extended surface is termed a spine. Practically there are situations which necessitate the increase of heat transfer rate. There are three ways with in which the heat transfer rate may be increased:

- Increasing the convection coefficient ' $h$ ' by increasing the fluid velocity

- Increasing the convection coefficient ' $h$ ' by decreasing the temperature

- Increasing the heat transfer rate by increasing the surface area over which the convection occurs

In the first two cases the heat transfer rate is increased by increasing the heat transfer coefficient of the surrounding fluid. In the first case the heat transfer coefficient is increased by speeding up fluid flow by the introduction of blowers, however there are situations for which increasing $\mathrm{h}$ to the maximum possible value is either insufficient to obtain the required heat transfer rate or the associated prices are preventive. Moreover the second case of reducing the fluid temperature is often impractical.

The third option is the most preferable; highlighting the increase in heat transfer rate by increasing the surface area across which convection occurs. This may be done by employing spines.

\section{TYPES OF SPINES}

Spine is an extra surface provided over the actual component from which heat transfer to the surroundings is to be enhanced. Selection and arrangement of spines is effected by several factors. Spines come in many shapes and sizes. They can be broadly classified into

- Surface spines of constant crosssection Rectangular spines

- Spines of varying cross-section. Tapered spines.

\section{GENERALIZED HEAT CONDUCTION EQUATIONS IN 3-D FOR ISOTROPIC MATERIAL:}

Cartesian coordinates:

Cylindrical coordinates:

$$
\frac{\partial^{2} T}{\partial X^{2}}+\frac{\partial^{2} T}{\partial Y^{2}}+\frac{\partial^{2} T}{\partial Z^{2}}+\frac{q}{k}=\frac{1}{\propto} \frac{\partial T}{\partial t}
$$

$$
\frac{\partial^{2} T}{\partial r^{2}}+\frac{1}{r}\left(\frac{\partial T}{\partial t}\right)+\frac{1}{r^{2}} \frac{\partial^{2} T}{\partial \phi^{2}}+\frac{\partial^{2} T}{\partial Z^{2}}+\frac{q}{k}=\frac{1}{\propto} \frac{\partial T}{\partial t}
$$

Spherical coordinates:

$$
\begin{gathered}
\frac{1}{r} \frac{\partial^{2}(r T)}{\partial r^{2}}+\frac{1}{r^{2} \sin \varphi} \frac{\partial}{\partial \varphi}\left(\sin \varphi \frac{\partial T}{\partial \varphi}\right)+\frac{1}{r^{2} \sin ^{2} \varphi} \frac{\partial^{2} T}{\partial \phi^{2}} \\
+\frac{q}{k}=\frac{1}{\alpha} \frac{\partial T}{\partial t}
\end{gathered}
$$

\section{TYPICAL APPLICATION AREAS OF} FINS ARE:

- Radiators for automobiles

- Cylinder heads Air-cooling of internal combustion engines like Scooters, motor cycles, aircraft engines, air compressors etc.

- Steam power plants economizers 
- Wide variety heat exchangers which are used in different industries

- Cooling of electric motors transformers, etc.

- Cooling of electronic equipment, chips, IC boards, etc.

- Fin theory is also used to estimate error in temperature measurement while using thermometers or thermocouples.

\section{CONVECTIVE HEAT TRANSFER}

Convection is one of the modes of heat transfer that is possible only in the fluid medium. When a fluid flows inside a duct or over a solid body and the temperatures of the fluid and solid body are different, heat transfer between the fluid and the solid surface take place. This is because of the motion of the fluid relative to the surface. This type of heat transfer is called convection. The transfer of heat here is inseparably linked with the movement of the fluid itself. Depending up on the movement of the fluid whether it is natural or artificial, convection is classified in to Natural convection and forced convection.

\subsection{Natural Convection:}

There are some situations in which the fluid motion is produced due to change in density resulting from temperature gradients. The mechanism of heat transfer in these situations is called natural convection. The movement of fluid in free convection is due to the fact that the fluid particles in the immediate vicinity to hot solid boundary become warmer (becomes less dense molecules) than the surrounding fluid resulting (high dense molecules due to low temperature). These low dense molecules of the fluid would be replaced by colder fluid resulting in what is called convection currents. These currents originate when a body force acts on a fluid in which there are density gradients. The force which induces these convection currents are called buoyancy force which is due to the density gradient within the fluid and the body force. There are many a number of correlations provided with, to study about different conditions of this natural convection. But, here in this experiment we are considered about the free convection over horizontal cylinder.

\subsection{Forced Convection:}

In forced convection, the fluid is forced to flow over a surface or in a tube by external means such as pump or blower. Convective heat transfer is complicated since it involves fluid motion as well as heat conduction. The convective heat transfer coefficient strongly depends on fluid properties and roughness of the solid surface and type of the fluid flow (laminar or turbulent). The flow in the boundary layer starts as smooth and streamlined which is called laminar flow. At some distance from the leading edge, the flow turns chaotic, which is called turbulent flow. Here in our experiment we are considered about the forced convection over horizontal cylinder.

\section{EXPERIMENTAL SETUP:}

The experimental set up consists of a simple spine which is fitted in a rectangular duct provided with a open cover over the spine. Exit end of the duct is attached to the suction end of the blower; one end of the spine is fitted to an electrical heater. A manometer is provided at the exit end of the duct to not the exit pressure of the fluid. Temperature of the spine is raised by using heater provided at the base plate, well insulated electrically and thermally to prevent heat loss and shocks. The heater is connected to an electric supply line through a wattmeter. The blower is operated only during forced convection. The base plate and spine assembly was made of aluminum (or brass) and casted together. The spine is provided with thermocouples located along the length of the spine and a thermocouple is provided to note the duct fluid temperature. Experiment is conducted on aluminum spine. 
International Journal of Research in Advent Technology, Vol.7, No.3, March 2019

E-ISSN: 2321-9637

Available online at www.ijrat.org

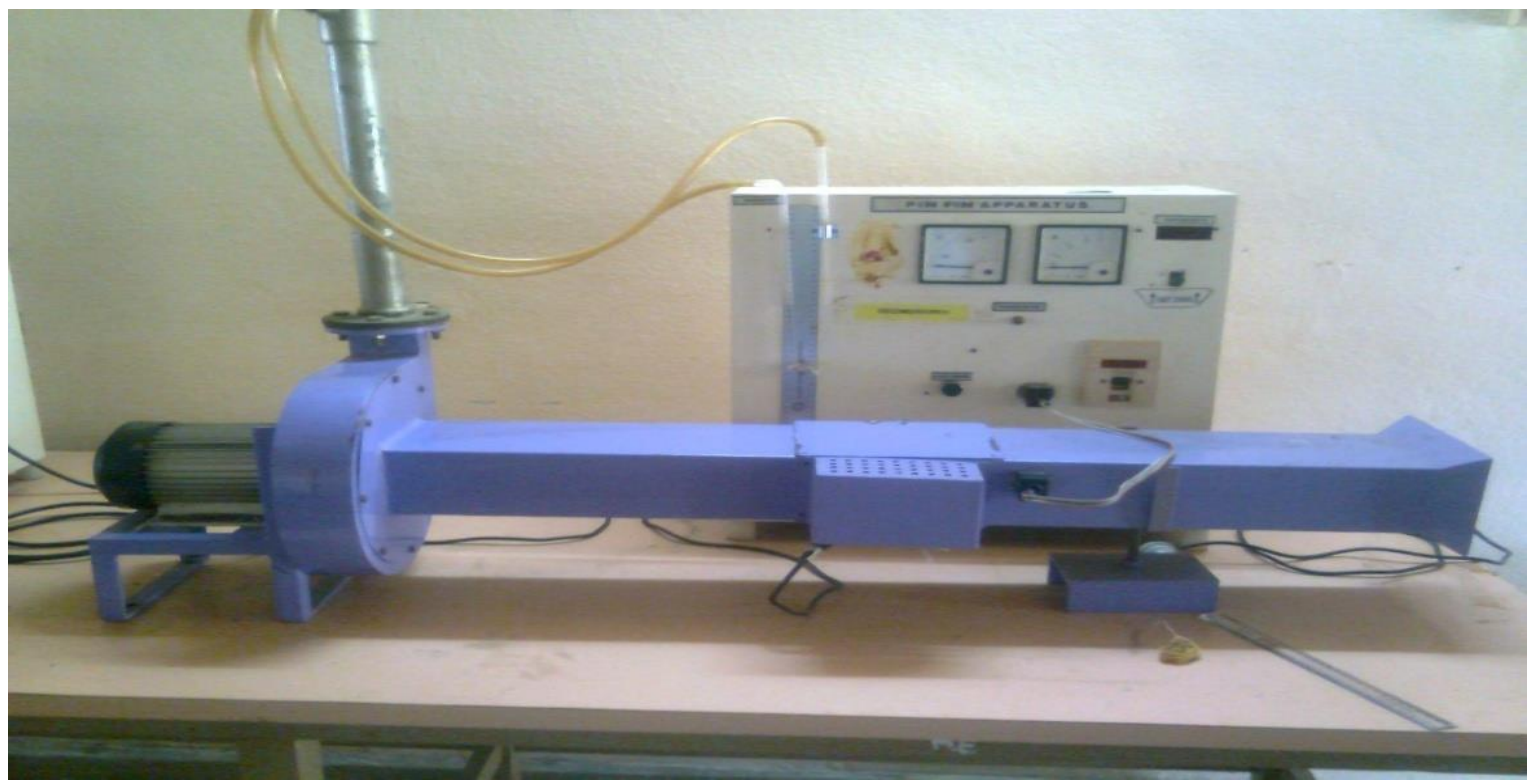

Figure 1: Experimental setup

\section{EXPERIMENTAL CONDITIONS}

The heat input to the spines is varied from $45-66 \mathrm{~W}$. In forced convection, the Reynold's number is varied from $2000-5000$ by regulating the flow control valve provided. Under these conditions, performance of the spines is studied.

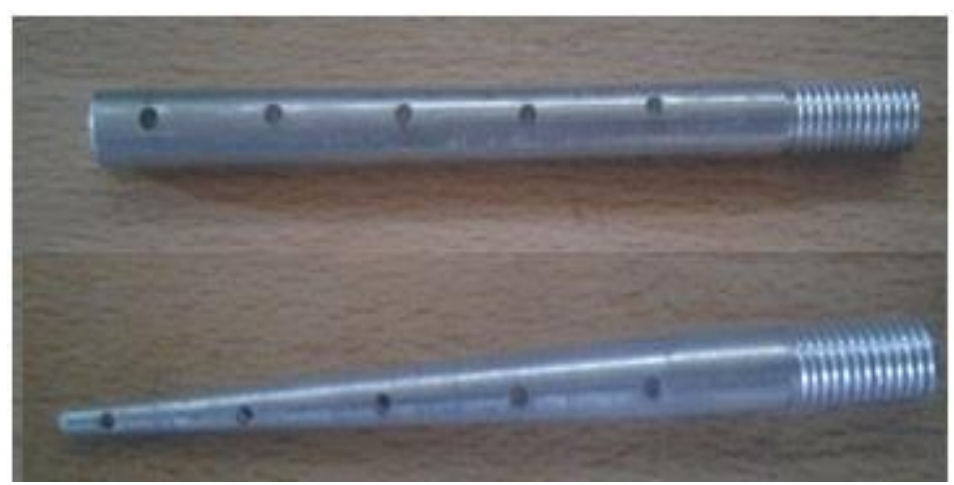

Figure 2: Tapered spines of different Tip diameters $(4,6,8 \mathrm{~mm})$

\section{CALCULATION FOR FORCED CONVECTION (PLAIN CYLINDRICAL FIN) For $Q=45 w$}

$$
Q=C_{d} \frac{\pi}{4} d^{2} \sqrt{2 g h\left(\rho_{w} / \rho_{a}\right)}=
$$

$0.64 \times \frac{\pi}{4} \times\left(22 \times 10^{-3}\right)^{2} \sqrt{2 \times 9.81 \times 0.101\left(\frac{1000}{1.121}\right)}$ $=0.0102 \mathrm{~m}^{3} / \mathrm{s}$.

$$
\mathrm{V}=\mathrm{Q} / \text { Duct cross sectional area }=\frac{0.01022}{0.15 \times 0.1}
$$

$=0.6819 \mathrm{~m} / \mathrm{s}$

$$
\mathrm{V}_{\mathrm{tmf}}=\frac{v\left(T_{m f}+273\right)}{T_{f}+273}=
$$

$$
\begin{aligned}
& \frac{0.6819(41.79+273)}{33.7+273}=0.699 \mathrm{~m} / \mathrm{s} \\
& \mathrm{Re}=\left(\mathrm{V}_{\mathrm{tmf}} \cdot \mathrm{D}_{\mathrm{h}}\right) / \mathrm{v}=4932.26 \\
& \mathrm{Nu}=0.193(\mathrm{Re})^{0.618} \cdot \mathrm{Pr}^{0.333} \\
& =0.193(4932.26)^{0.618} \cdot(0.6988)^{0.333} \\
& =32.9039 \\
& \mathrm{Nu}=\frac{h D}{K_{\text {airA }}} \\
& \mathrm{h}=76.5425 \mathrm{w} / \mathrm{m}^{2} \mathrm{k}
\end{aligned}
$$


International Journal of Research in Advent Technology, Vol.7, No.3, March 2019

E-ISSN: 2321-9637

Available online at www.ijrat.org

$$
\mathrm{m}=\sqrt{\frac{h p}{k_{f} A}}
$$

$$
\begin{aligned}
& \qquad Q_{\text {fin }}=\sqrt{h p k A}\left(T-T_{f}\right) \frac{\sinh m L+\frac{h}{m k} \cosh m L}{\cosh m L+\frac{h}{m k} \sinh m L} \\
& =9.6417 \mathrm{w} \\
& =7.29 \text { Effectiveness of the fin } \quad \epsilon_{\text {fin }}=\frac{Q_{\text {fin }}}{h A_{b}\left(T_{b}-T_{a}\right)}
\end{aligned}
$$$$
\text { The obtained results are tabulated and presented }
$$

\begin{tabular}{|c|c|c|c|c|c|c|c|}
\hline \multicolumn{2}{|c|}{ Heat input } & \multirow[b]{2}{*}{$\begin{array}{c}\text { Grasshoff } \\
\text { number }\end{array}$} & \multirow[b]{2}{*}{$\begin{array}{l}\text { Prandtl } \\
\text { Number }\end{array}$} & \multirow[b]{2}{*}{$\begin{array}{l}\text { Nusselt } \\
\text { number }\end{array}$} & \multirow[b]{2}{*}{$\mathrm{h}\left(\mathrm{w} / \mathrm{m}^{2} \mathrm{k}\right)$} & \multirow[b]{2}{*}{$\begin{array}{l}\mathrm{Q}_{\text {spine }} \\
\text { (watt) }\end{array}$} & \multirow[t]{2}{*}{ Effectivenes } \\
\hline $\begin{array}{l}\text { Voltage } \\
\text { (Volts) }\end{array}$ & $\begin{array}{l}\text { Current } \\
\text { (Amps) }\end{array}$ & & & & & & \\
\hline 90 & 0.5 & 8965.6580 & 0.6942 & 4.3924 & 10.7980 & 3.34 & 9.62 \\
\hline 100 & 0.56 & 9535.9193 & 0.6931 & 4.4423 & 11.1057 & 4.02 & 9.6 \\
\hline 110 & 0.6 & 10180.0758 & 0.69212 & 4.496 & 11.3974 & 4.96 & 9.59 \\
\hline
\end{tabular}
graphically, and discussed in detail

Performance of straight plain spine and tapered spine

\begin{tabular}{|c|c|c|c|c|c|c|c|}
\hline \multicolumn{2}{|c|}{ Heat input } & \multirow{2}{*}{$\begin{array}{c}\text { Manometer } \\
\text { reading } \\
\mathrm{H}(\mathrm{mm})\end{array}$} & \multirow[b]{2}{*}{$\begin{array}{l}\text { Reynold's } \\
\text { Number }\end{array}$} & \multirow[b]{2}{*}{$\begin{array}{l}\text { Nusselt } \\
\text { Number }\end{array}$} & \multirow[b]{2}{*}{$\mathrm{h}\left(\mathrm{w} / \mathrm{m}^{2} \mathrm{k}\right)$} & \multirow[b]{2}{*}{$\begin{array}{c}\mathrm{Q}_{\text {Spine }} \\
\text { (watts) }\end{array}$} & \multirow{2}{*}{$\begin{array}{c}\text { Effectiv } \\
\text { eness }\end{array}$} \\
\hline $\begin{array}{l}\text { Voltage } \\
\text { (Volts) }\end{array}$ & $\begin{array}{l}\text { Current } \\
\text { (Amps) }\end{array}$ & & & & & & \\
\hline 90 & 0.5 & 101 & 4932.26 & 32.9039 & 76.5425 & 9.6417 & 7.29 \\
\hline 90 & 0.5 & 75 & 4258.04 & 29.9554 & 69.9209 & 9.4078 & 7.47 \\
\hline 90 & 0.5 & 50 & 3473.79 & 27.0708 & 63.1652 & 9.0001 & 7.65 \\
\hline 90 & 0.5 & 25 & 2455.90 & 23.0349 & 53.3643 & 6.3301 & 7.94 \\
\hline 100 & 0.56 & 101 & 4931.14 & 32.9008 & 78.2377 & 9.7555 & 7.25 \\
\hline 100 & 0.56 & 75 & 4248.64 & 29.9145 & 69.8005 & 9.2772 & 7.47 \\
\hline 100 & 0.56 & 50 & 3470.05 & 27.0576 & 63.0884 & 8.465 & 7.65 \\
\hline 100 & 0.56 & 25 & 2454.40 & 23.0272 & 52.4638 & 6.4499 & 7.97 \\
\hline 110 & 0.6 & 101 & 4910.22 & 32.8052 & 77.1304 & 13.7098 & 7.28 \\
\hline 110 & 0.6 & 75 & 4220.83 & 29.7805 & 68.7434 & 13.2787 & 7.50 \\
\hline 110 & 0.6 & 50 & 3449.49 & 26.9721 & 63.8339 & 12.409 & 7.63 \\
\hline 110 & 0.6 & 25 & 2427.39 & 22.9034 & 53.823 & 9.0058 & 7.93 \\
\hline
\end{tabular}
(circular section) at different heat inputs is studied.

Table 1: Results obtained for cylindrical spine Natural convection:[prismatic bar]

\begin{tabular}{|c|c|c|c|c|c|c|c|}
\hline \multicolumn{2}{|c|}{ Heat input } & \multirow[b]{2}{*}{$\begin{array}{c}\text { Grasshoff } \\
\text { number }\end{array}$} & \multirow[b]{2}{*}{$\begin{array}{l}\text { Prandtl } \\
\text { Number }\end{array}$} & \multirow[b]{2}{*}{$\begin{array}{l}\text { Nusselt } \\
\text { number }\end{array}$} & \multirow[b]{2}{*}{$\mathrm{h}\left(\mathrm{w} / \mathrm{m}^{2} \mathrm{k}\right)$} & \multirow[b]{2}{*}{$\begin{array}{l}\mathrm{Q}_{\text {spine }} \\
\text { (watt) }\end{array}$} & \multirow{2}{*}{$\begin{array}{c}\text { Effectiv } \\
\text { eness }\end{array}$} \\
\hline $\begin{array}{l}\text { Voltage } \\
\text { (Volts) }\end{array}$ & $\begin{array}{l}\text { Current } \\
\text { (Amps) }\end{array}$ & & & & & & \\
\hline 90 & 0.5 & 8677.679 & 0.6943 & 4.3656 & 10.7504 & 1.8156 & 16.6471 \\
\hline 100 & 0.56 & 9300.5759 & 0.6934 & 4.4218 & 11.0030 & 2.1555 & 16.6399 \\
\hline 110 & 0.6 & 9419.9579 & 0.6923 & 4.4311 & 11.1960 & 2.4026 & 16.6296 \\
\hline
\end{tabular}

Table 2: Results obtained for plain cylindrical spine forced convection [prismatic bar]

Table 3: Results obtained for tapered spine [end dia $=4 \mathrm{~mm}$ ]Natural convection: 
International Journal of Research in Advent Technology, Vol.7, No.3, March 2019 E-ISSN: 2321-9637

Available online at www.ijrat.org

Table 4: Results obtained for plain tapered spine [end dia $=4 \mathrm{~mm}]$ forced convection

\begin{tabular}{|c|c|c|c|c|c|c|c|}
\hline \multicolumn{2}{|c|}{ Heat input } & \multirow{2}{*}{$\begin{array}{l}\text { Manometer } \\
\text { reading } \\
\mathrm{H}(\mathrm{mm})\end{array}$} & \multirow[b]{2}{*}{$\begin{array}{l}\text { Reynold's } \\
\text { Number }\end{array}$} & \multirow[b]{2}{*}{$\begin{array}{l}\text { Nusselt } \\
\text { Number }\end{array}$} & \multirow[b]{2}{*}{$\mathrm{h}\left(\mathrm{w} / \mathrm{m}^{2} \mathrm{k}\right)$} & \multirow[b]{2}{*}{$\begin{array}{l}\mathrm{Q}_{\text {Spine }} \\
\text { (watts) }\end{array}$} & \multirow{2}{*}{$\begin{array}{c}\text { Effectiv } \\
\text { Eness }\end{array}$} \\
\hline $\begin{array}{l}\text { Voltage } \\
\text { (Volts) }\end{array}$ & $\begin{array}{l}\text { Current } \\
\text { (Amps) }\end{array}$ & & & & & & \\
\hline 90 & 0.5 & 101 & 4990.8692 & 33.0521 & 76.1025 & 5.0461 & 14.7677 \\
\hline 90 & 0.5 & 75 & 4291.4033 & 30.1073 & 69.4226 & 4.8065 & 14.9313 \\
\hline 90 & 0.5 & 50 & 3500.1571 & 27.1754 & 62.7456 & 4.5661 & 15.1047 \\
\hline 90 & 0.5 & 25 & 2486.2407 & 23.1737 & 53.0099 & 3.1499 & 15.3625 \\
\hline 100 & 0.56 & 101 & 4973.23 & 32.9783 & 76.2899 & 6.024 & 14.7608 \\
\hline 100 & 0.56 & 75 & 4282.9562 & 30.0678 & 69.6071 & 5.5464 & 14.9268 \\
\hline 100 & 0.56 & 50 & 3497.0559 & 27.163 & 62.8082 & 4.7037 & 14.4266 \\
\hline 100 & 0.56 & 25 & 2478.845 & 23.1382 & 53.1987 & 3.585 & 15.3500 \\
\hline 110 & 0.6 & 101 & 4925.1272 & 32.773 & 76.7708 & 7.9401 & 14.7499 \\
\hline 110 & 0.6 & 75 & 4244.5923 & 29.894 & 70.1513 & 7.5128 & 14.9122 \\
\hline 110 & 0.6 & 50 & 3464.6389 & 27.0349 & 63.442 & 6.8304 & 15.0866 \\
\hline 110 & 0.6 & 25 & 2449.4264 & 23.0022 & 53.8443 & 5.7176 & 15.3416 \\
\hline
\end{tabular}

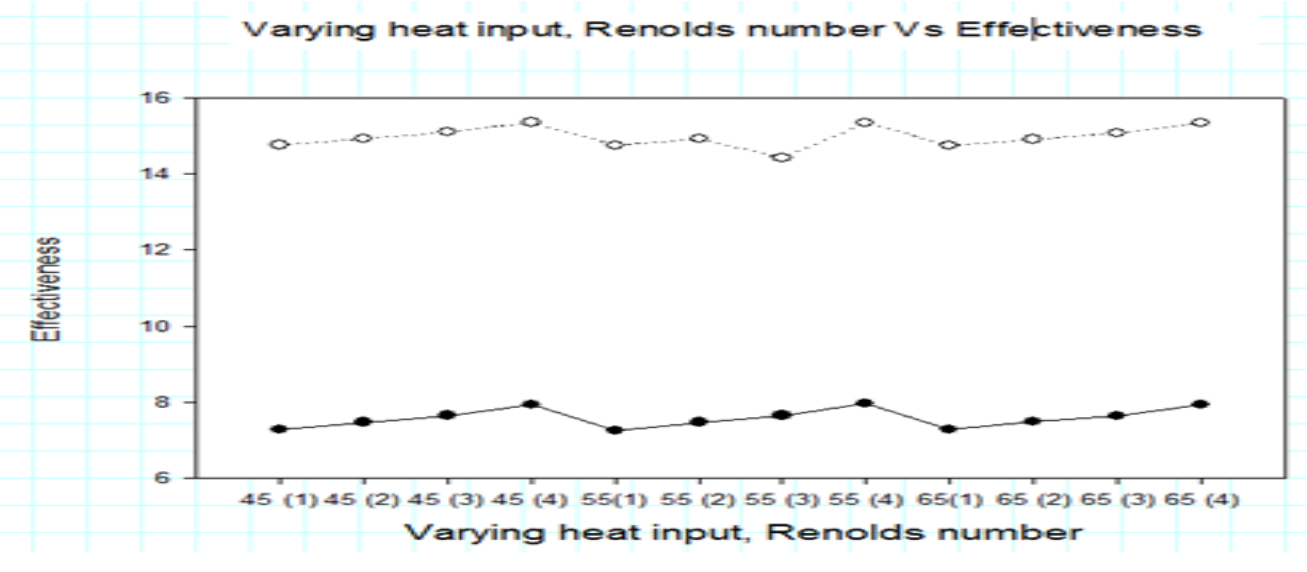


International Journal of Research in Advent Technology, Vol.7, No.3, March 2019

E-ISSN: 2321-9637

Available online at www.ijrat.org

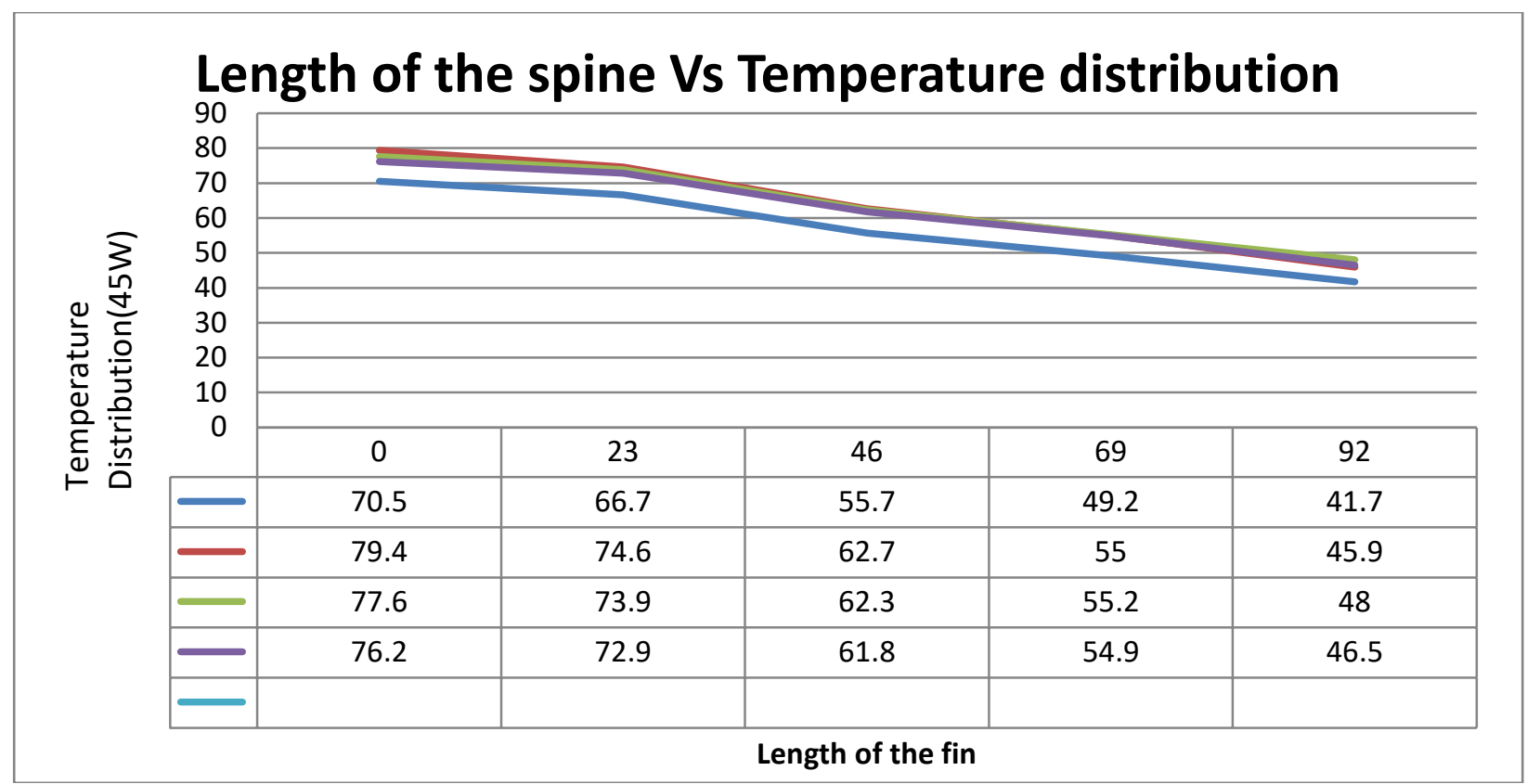

\section{ACKNOWLEDGEMENTS:}

The satisfaction that accompanies the successful completion of any task would be incomplete without the mention of people who made it possible and whose constant guidance and encouragement crown all the efforts with success. We would like to express our deep sense of gratitude and sincere thanks to the management and to our beloved Principal Dr. P. Ravindra Babu, for his constant guidance, supervision and motivation in completing this paper work. We feel happy to extend our floral gratitude to Dr.M.R.Ch. Sastry, Head of the Department, for his encouragement in all the way during the progress of this paper and we also express our thanks to Teaching and Non-Teaching Staff of Mechanical Engineering who helped us directly or indirectly in completion of our work.

\section{REFERENCES}

[1] "IftakharAlam and P.S. Ghoshdastidar" A study of heat transfer effectiveness of circular tubes with internal longitudinal fins having tapered lateral profiles. International Journal of Heat and Mass Transfer 45 (2002) 1371-1376.

[2] "Kundu.B and Das P. K" Performance and Optimization Analysis for Fins of Straight Taper with Simultaneous Heat and Mass Transfer. 2004, ASME Journal of Heat and mass transfer 126, pp. 862-868.

[3] "MasoudAsadi and NasrinDindarMehrabani" An approach to optimal fin diameter based on entropy minimization. International Journal of
Innovation and Applied Studies ISSN 20289324 Vol. 2 No. 4 Apr. 2013, pp. 518-524.

[4] "Jitamitra Swain, Kumar Gaurav, Dheerendra Singh, Prakash Kumar Sen, and Shailendra Kumar Bohidar" Comparative Study on Heat Transfer in Straight Triangular Fin and Porous Pin Fin under Natural Convection. International Journal of Innovation and Scientific Research ISSN 2351-8014 Vol. 11 No. 2 Nov. 2014, pp. 611-619.

[5] Fundamentals of Engineering Heat and Mass Transfer 4th Edition by R.C.Sachadeva. 